\title{
ПРОГНОЗУВАННЯ ПЕРЕБІГУ ХІРУРГІЧНОГО ЛІКУВАННЯ РОЗЛИТОГО ПЕРИТОНІТУ З УРАХУВАННЯМ КІЛЬКІСНОЇ ОЦІНКИ ФАКТОРІВ РИЗИКУ
}

\author{
Івано-Франківський
}

національний

медичний

I. К. Чурпій

Досліджена можливість кількісного оцінювання факторів ризику виникнення ускладнень при лікуванні розлитого перитоніту. Виділено 70 груп ознак, що мають значення при прогнозуванні перебігу розлитого перитоніту. Запропонована схема визначення ризику клінічного перебігу розлитого перитоніту дозволяє кількісно оцінити тяжкість вихідного стану хворих й у більшості випадків правильно спрогнозувати результати лікування захворювання.

Ключові слова: перитоніт, фактори ризику, прогнозування ускладнень.

\section{ПРОГНОЗИРОВАНИЕ ТЕЧЕНИЯ ХИРУРГИЧЕСКОГО ЛЕЧЕНИЯ РАСПРОСТРАНЕННОГО ПЕРИТОНИТА С УЧЕТОМ КОЛИЧЕСТВЕННОЙ ОЦЕНКИ ФАКТОРОВ РИСКА}

\author{
Ивано-Франковский
}

национальный

медицинский

университет

И. К. Чурпий

Исследована возможность количественной оценки факторов риска, которые могут привести к возникновению осложнений при распространенном перитоните. Выделено 70 наиболее важных факторов риска, имеющих значение в прогнозировании течения заболевания.

Ключевые слова: перитонит, факторы риска, прогнозирование осложнений.

\section{PREDICTION OF SURGICAL TREATMENT WITH POUR PERITONITIS TAKING INTO ACCOUNT QUANTIFYING RISK FACTORS}

I. K. Churpiy

Ivano-Frankivsk National Medical University

There was investigated the possibility of quantitative assessment of risk factors of complications in the treatment of diffuse peritonitis. There were ditermined 70 groups of features that are important in predicting the course of diffuse peritonitis. The proposed scheme is the definition of risk clinical course of diffuse peritonitis can quantify the severity of the original patients and in most cases is correctly to predict the results of treatment of disease.

Key words: peritonitis, factors risk, prognosis complication.

Вступ. За останні десятиліття, незважаючи на впровадження нових методів лікування, застосування антибіотиків останніх поколінь, повторних лапаротомій 3 санацією черевної порожнини - летальність від перитоніту практично не змінилася, що спонукає фахівців критично оцінювати сучасну методологію лікування, засновану на посиндромному підході $[1,2]$.

Оптимізація роботи хірурга, особливо у діагностично складних і важко передбачуваних ситуаціях, потребує здебільшого не тільки глибоких знань та практичних навиків, а й вміння проаналізувати дані, скласти алгоритм дій та спрогнозувати результат [3].
Застосування інформаційних технологій і математичних методів дозволяє істотно підвищити якість, раціональність медичної діагностики і лікувального процесу. Аналітичні способи вирішення діагностичних завдань і планування лікувальних заходів дозволяють оптимізувати процес лікування [4, 5].

Метою дослідження було визначення прогностичної значимості найважливіших клінічних ознак як факторів ризику для прогнозування перебігу та результату лікування розлитого перитоніту.

Матеріал і методи. Здійснений ретроспективний аналіз 200 медичних карт стаціонарних хворих з роз-

(c) І. К. Чурпій 
литим перитонітом різної етіології. Всі обстеження проводилися при надходженні в клініку (до початку лікування) та після інтраопераційної санації черевної порожнини.

Структура патології була наступною: гострий перфоративний апендицит (I ПА) - 15, гострий калькульозний холецистит (ГКХ) - 9, перфоративна виразка шлунка - 17, перфоративна виразка ДПК - 36, гостра кишкова непрохідність - 40, защемлена грижа - 18, апоплексія - 1, гострий тромбоз мезентеріальних судин - 6, травми органів черевної порожнини - 16, перфорація кишки - 11, рак - 28, хвороба Крона - 3 випадки.

3200 хворих померло 28 (14\%). Кількість спостережень характеризує можливість визначення прогностичної цінності факторів ризику при хірургічному лікуванні розлитого перитоніту з високим ступенем вірогідності.

Всім хворим здійснювали загальноклінічне обстеження: збір скарг, анамнезу хвороби, фізикальне обстеження, клініко-лабораторні обстеження та їх інтегральну оцінку.

Основою вивчення передопераційного, інтра- та післяопераційного стану хворих, а також прогнозування перебігу захворювання становили фактори ри- зику. Їх визначали шляхом оцінки значення клінічних показників в визначенні ймовірності виникнення ускладнень під час лікування хворих.

Відповідно, на першому етапі дослідження була створена карта автоматизованого обліку хворого 3 перитонітом, яка включала дані клініко-лабораторних обстежень, відомості анамнезу і операційні знахідки.

Кількісні значення прогностичної значимості клінічної інформації здійснювали з використанням методики М. М. Амосова та співавторів [6].

Всього аналізували 174 ознаки перитоніту, що включали дані анамнезу, клінічного обстеження, лабораторних, спеціальних й інструментальних методів обстеження.

Результати та обговорення. На підставі дослідження й аналізу 22 груп клінічних ознак та їх градацій (шаблонів), що вивчалися для виявлення факторів ризику перебігу перитоніту (табл. 1) було відібрано 70 найбільш значимих факторів для прогнозування результату захворювання (табл. 2). Фактори представлені з позитивними та негативними значеннями, тобто вони можуть мати позитивне i негативне значення для прогнозу.

В нашому дослідженні застосовували алгоритм використання лише позитивних значень факторів ри-

Таблиця 1. Групи клінічних ознак та їх градації (шаблони), що вивчалися для виявлення факторів ризику перебігу перитоніту

\begin{tabular}{|c|c|c|c|c|c|c|}
\hline & \multirow{3}{*}{ Фактор } & \multirow[t]{3}{*}{. } & \multicolumn{3}{|c|}{ Результат } & \\
\hline & & & \multirow{2}{*}{$\begin{array}{c}\text { добрий } \\
\text { осіб }\end{array}$} & \multicolumn{2}{|c|}{ несприятливий } & \\
\hline & & & & осіб & $\%$ & \\
\hline 1. & Чоловіча стать & 126 & 111 & 15 & 11,9 & $-0,41$ \\
\hline 2. & Жіноча стать & 74 & 61 & 13 & 17,6 & 0,71 \\
\hline 3. & $\begin{array}{l}\text { Biк: } \\
18-20 \\
21-40 \\
41-50 \\
51-60 \\
61-75 \\
76-90 \\
>90 \\
\end{array}$ & $\begin{array}{c}8 \\
56 \\
43 \\
23 \\
40 \\
29 \\
1\end{array}$ & $\begin{array}{c}8 \\
54 \\
41 \\
20 \\
31 \\
18 \\
0\end{array}$ & $\begin{array}{c}0 \\
2 \\
2 \\
3 \\
9 \\
11 \\
1\end{array}$ & $\begin{array}{c}0 \\
3,6 \\
4,6 \\
13,1 \\
22,5 \\
37,9 \\
100\end{array}$ & $\begin{array}{c}0 \\
-1,43 \\
-1,36 \\
-0,42 \\
1,29 \\
2,17 \\
4,13\end{array}$ \\
\hline 4. & $\begin{array}{l}\text { Поширеність перитоніту: } \\
\text { Розлитий }\end{array}$ & 200 & 172 & 28 & 14 & 2,24 \\
\hline 5. & $\begin{array}{l}\text { Термін госпіталізації: } \\
\text { До } 6 \text { год. } \\
\text { 6-12 год. } \\
\text { 12-24 год. } \\
\text { 24-48 год. } \\
\text { 48-72 год. } \\
\text { >72 год. }\end{array}$ & $\begin{array}{l}16 \\
63 \\
52 \\
30 \\
15 \\
24\end{array}$ & $\begin{array}{l}16 \\
59 \\
51 \\
21 \\
10 \\
14\end{array}$ & $\begin{array}{c}0 \\
4 \\
1 \\
9 \\
5 \\
10\end{array}$ & $\begin{array}{c}0 \\
6,4 \\
1,9 \\
30 \\
33,3 \\
41,7\end{array}$ & $\begin{array}{c}0 \\
-1,23 \\
-1,53 \\
1,78 \\
1,95 \\
2,34\end{array}$ \\
\hline 6. & $\begin{array}{l}\text { Місцевість проживання: } \\
\text { Місто } \\
\text { Село } \\
\end{array}$ & $\begin{array}{l}147 \\
53\end{array}$ & $\begin{array}{l}137 \\
35\end{array}$ & $\begin{array}{l}10 \\
18\end{array}$ & $\begin{array}{l}6,8 \\
34\end{array}$ & $\begin{array}{r}-1,19 \\
1,99\end{array}$ \\
\hline
\end{tabular}


Продовження табл. 1

\begin{tabular}{|c|c|c|c|c|c|c|}
\hline \multirow{3}{*}{$\begin{array}{l}\text { № } \\
3 / \Pi\end{array}$} & \multirow{3}{*}{ Фактор } & \multirow{3}{*}{$\begin{array}{c}\text { Кількість } \\
\text { спостережень }\end{array}$} & \multicolumn{3}{|c|}{ Результат } & \multirow{3}{*}{$\begin{array}{c}\text { Значення, } \\
\text { бали }\end{array}$} \\
\hline & & & \multirow{2}{*}{$\begin{array}{c}\text { добрий } \\
\text { осіб }\end{array}$} & \multicolumn{2}{|c|}{ несприятливий } & \\
\hline & & & & осіб & $\%$ & \\
\hline 7. & $\begin{array}{l}\text { Перенесені захворювання, } \\
\text { шкідливі звички: } \\
\text { Інсульт } \\
\text { Інфаркт міокарда } \\
\text { Гепатит } \\
\text { Перенесені операції на ОЧП } \\
\text { Травми ОЧП } \\
\text { Алергічні захворювання } \\
\text { Вживання алкоголю } \\
\text { Куріння }\end{array}$ & $\begin{array}{l}21 \\
35 \\
36 \\
38 \\
11 \\
11 \\
22 \\
62\end{array}$ & $\begin{array}{l}10 \\
17 \\
23 \\
31 \\
10 \\
9 \\
19 \\
48\end{array}$ & $\begin{array}{l}11 \\
18 \\
13 \\
7 \\
1 \\
2 \\
3 \\
14\end{array}$ & $\begin{array}{l}52,4 \\
51,4 \\
36,1 \\
18,4 \\
9,09 \\
18,2 \\
13,6 \\
22,6\end{array}$ & $\begin{array}{c}2,75 \\
2,72 \\
2,09 \\
0,93 \\
-0,98 \\
0,91 \\
-0,28 \\
1,3\end{array}$ \\
\hline 8. & $\begin{array}{l}\text { Етіологічний чинник: } \\
\text { Гострий перфоративний апендицит } \\
\text { Гострий калькульозний холецистит } \\
\text { Защемлена грижа } \\
\text { Апоплексія ячників } \\
\text { Гостра кишкова непрохідність } \\
\text { Перфоративна виразка шлунка } \\
\text { Перфоративна виразка ДПК } \\
\text { Гострий тромбоз мезентеріальних } \\
\text { судин } \\
\text { Травми ОЧП } \\
\text { Перфорація кишки } \\
\text { Рак } \\
\text { Хвороба Крона }\end{array}$ & $\begin{array}{c}15 \\
9 \\
18 \\
1 \\
40 \\
17 \\
36 \\
5 \\
\\
16 \\
12 \\
28 \\
3\end{array}$ & $\begin{array}{c}14 \\
7 \\
14 \\
1 \\
33 \\
15 \\
36 \\
0 \\
\\
14 \\
10 \\
25 \\
3\end{array}$ & $\begin{array}{l}1 \\
2 \\
4 \\
0 \\
7 \\
2 \\
0 \\
5 \\
\\
2 \\
2 \\
3 \\
0\end{array}$ & $\begin{array}{c}6,7 \\
22,2 \\
22,2 \\
0 \\
17,5 \\
11,8 \\
0 \\
100\end{array}$ & $\begin{array}{c}1,20 \\
1,27 \\
1,27 \\
0 \\
0,83 \\
-0,66 \\
0 \\
4,13 \\
\\
-0,54 \\
0,73 \\
-0,81 \\
0\end{array}$ \\
\hline 9. & $\begin{array}{l}\text { Характер ексудату: } \\
\text { Серозний } \\
\text { Серозно-фібринозний } \\
\text { Гнійний } \\
\text { Гнійно -фібринозний } \\
\text { Жовчний } \\
\text { Геморагічний } \\
\text { Каловий }\end{array}$ & $\begin{array}{c}9 \\
81 \\
26 \\
38 \\
7 \\
14 \\
25 \\
\end{array}$ & $\begin{array}{c}9 \\
80 \\
21 \\
29 \\
5 \\
11 \\
17\end{array}$ & $\begin{array}{l}0 \\
1 \\
5 \\
9 \\
2 \\
3 \\
8\end{array}$ & $\begin{array}{c}0 \\
1,2 \\
19,2 \\
23,7 \\
28,6 \\
21,4 \\
32\end{array}$ & $\begin{array}{c}0 \\
-1,59 \\
1,04 \\
1,38 \\
1,70 \\
1,21 \\
1,89\end{array}$ \\
\hline 10. & $\begin{array}{l}\text { Супутня патологія: } \\
\text { ІХС, кардіосклероз } \\
\text { Порушення серцевого ритму } \\
\text { Гіпертонічна хвороба II-III ст. } \\
\text { Цукровий діабет I тип } \\
\text { Цукровий діабет II тип } \\
\text { Ожиріння II-ІУ ст. } \\
\text { Анемія } \\
\text { Захворювання бронхів та легень } \\
\text { Захворювання печінки } \\
\text { Захворювання нирок } \\
\text { Ревматична хвороба серця } \\
\text { СНІД } \\
\text { Спайкова хвороба очеревини } \\
\text { Варикозна хвороба нижніх кінцівок } \\
\text { Захворювання підшлункової залози } \\
\text { Виразкова х-ба шлунка і ДПК }\end{array}$ & $\begin{array}{c}93 \\
40 \\
78 \\
2 \\
20 \\
38 \\
17 \\
65 \\
38 \\
26 \\
23 \\
9 \\
63 \\
87 \\
22 \\
36 \\
\end{array}$ & $\begin{array}{c}69 \\
21 \\
53 \\
2 \\
16 \\
26 \\
12 \\
49 \\
27 \\
17 \\
14 \\
7 \\
45 \\
59 \\
16 \\
29 \\
\end{array}$ & $\begin{array}{c}24 \\
19 \\
25 \\
0 \\
4 \\
12 \\
5 \\
16 \\
11 \\
9 \\
9 \\
2 \\
18 \\
28 \\
6 \\
7 \\
\end{array}$ & $\begin{array}{c}25,8 \\
47,5 \\
32,1 \\
0 \\
20 \\
31,6 \\
29,4 \\
24,6 \\
28,9 \\
34,6 \\
39,1 \\
22,2 \\
28,6 \\
32,2 \\
27,3 \\
19,4 \\
\end{array}$ & $\begin{array}{c}1,53 \\
2,57 \\
1,89 \\
0 \\
1,09 \\
1,87 \\
1,75 \\
1,45 \\
1,72 \\
2,02 \\
2,23 \\
1,27 \\
1,70 \\
1,90 \\
1,62 \\
1,03 \\
\end{array}$ \\
\hline 11. & $\begin{array}{c}\text { Пульс: }(\text { уд/хв. })<70 \\
\begin{array}{c}<0-90 \\
90-110\end{array} \\
>110\end{array}$ & $\begin{array}{c}2 \\
17 \\
118 \\
63\end{array}$ & $\begin{array}{c}2 \\
16 \\
111 \\
53\end{array}$ & $\begin{array}{c}0 \\
1 \\
17 \\
10\end{array}$ & $\begin{array}{c}0 \\
5,9 \\
14,4 \\
15,9\end{array}$ & $\begin{array}{c}0 \\
-1,27 \\
0,28 \\
0,61\end{array}$ \\
\hline
\end{tabular}


Продовження табл. 1

\begin{tabular}{|c|c|c|c|c|c|c|}
\hline \multirow{3}{*}{$\begin{array}{l}\text { № } \\
3 / \Pi\end{array}$} & \multirow{3}{*}{ Фактор } & \multirow{3}{*}{$\begin{array}{c}\text { Кількість } \\
\text { спостережень }\end{array}$} & \multicolumn{3}{|c|}{ Результат } & \multirow{3}{*}{$\begin{array}{c}\text { Значення, } \\
\text { бали }\end{array}$} \\
\hline & & & \multirow{2}{*}{$\begin{array}{c}\text { добрий } \\
\text { осіб }\end{array}$} & \multicolumn{2}{|c|}{ несприятливий } & \\
\hline & & & & осіб & $\%$ & \\
\hline 12. & $\begin{array}{l}\text { Фази розвитку перитоніту: } \\
\text { Реактивна } \\
\text { Токсична } \\
\text { Термінальна }\end{array}$ & $\begin{array}{l}24 \\
133 \\
43\end{array}$ & $\begin{array}{c}24 \\
131 \\
17\end{array}$ & $\begin{array}{c}0 \\
2 \\
26\end{array}$ & $\begin{array}{c}0 \\
1,5 \\
60,5\end{array}$ & $\begin{array}{c}0 \\
-1,57 \\
3,03\end{array}$ \\
\hline 13. & $\begin{array}{l}\text { Об'см оперативних втручань: } \\
\text { Апендектомія } \\
\text { Ушивання виразки } \\
\text { Висічення виразки з тлоропластикою } \\
\text { Висічення виразки } 3 \\
\text { пілоропластикою +СПВ } \\
\text { Висічення виразки } 3 \\
\text { пілоропластикою+стов.вагот. } \\
\text { Ліквідація непрохідності } \\
\text { Ліквідація непрохідності + резекція } \\
\text { кишечника } \\
\text { Операція Гартмана } \\
\text { Правобічна геміколектомія } \\
\text { Виведення двостовбурового ануса } \\
\text { Ушивання рани печінки } \\
\text { Спленектомія } \\
\text { Грижовисікання } \\
\text { Грижовисікання+резекція кишечника } \\
\text { Холецистектомія (відкрита) } \\
\text { Лапароскопічна холецистектомія } \\
\text { Клиноподібна резекція яєчника } \\
\text { Лапароскопічна діагностика } \\
\text { Ушивання рани кишечника } \\
\text { Інтубація кишечника } \\
\text { Накладання обхідного анастомозу } \\
\text { Не оперований }\end{array}$ & $\begin{array}{c}15 \\
10 \\
18 \\
\\
18 \\
\\
7 \\
21 \\
\\
22 \\
12 \\
9 \\
8 \\
5 \\
10 \\
8 \\
9 \\
5 \\
3 \\
1 \\
11 \\
17 \\
51 \\
6 \\
1 \\
\end{array}$ & $\begin{array}{c}14 \\
9 \\
17 \\
18 \\
\\
7 \\
18 \\
\\
18 \\
10 \\
9 \\
4 \\
5 \\
9 \\
8 \\
5 \\
3 \\
3 \\
1 \\
7 \\
14 \\
42 \\
5 \\
0 \\
\end{array}$ & $\begin{array}{l}4 \\
2 \\
0 \\
4 \\
0 \\
1 \\
0 \\
4 \\
2 \\
0 \\
0 \\
4 \\
3 \\
9 \\
1 \\
1 \\
\end{array}$ & $\begin{array}{c}6,7 \\
10 \\
5,5 \\
\\
0 \\
\\
0 \\
14,3 \\
\\
18,2 \\
16,7 \\
0 \\
50 \\
0 \\
10 \\
0 \\
44,4 \\
40 \\
0 \\
0 \\
36,4 \\
17,6 \\
17,6 \\
16,7 \\
100 \\
\end{array}$ & $\begin{array}{c}-1,20 \\
-0,89 \\
-1,30 \\
0 \\
0 \\
0,24 \\
\\
0,91 \\
0,73 \\
0 \\
2,67 \\
0 \\
-0,89 \\
0 \\
2,45 \\
2,27 \\
0 \\
0 \\
2,11 \\
0,84 \\
0,84 \\
0,73 \\
4,13 \\
\end{array}$ \\
\hline 14. & $\begin{array}{l}\text { Тривалість операції: (хв) } \\
\text { До } 60 \\
60-90 \\
90-120 \\
120-180 \\
>180\end{array}$ & $\begin{array}{l}20 \\
22 \\
61 \\
85 \\
12 \\
\end{array}$ & $\begin{array}{c}16 \\
22 \\
59 \\
67 \\
8 \\
\end{array}$ & $\begin{array}{c}4 \\
0 \\
2 \\
18 \\
4 \\
\end{array}$ & $\begin{array}{c}20 \\
0 \\
3,28 \\
21,2 \\
33,3 \\
\end{array}$ & $\begin{array}{c}1,09 \\
0 \\
-1,45 \\
1,19 \\
1,95\end{array}$ \\
\hline 15. & $\begin{array}{l}\text { Розчини для санації черевної } \\
\text { порожнини: } \\
\text { Фурацилін } \\
\text { Декасан }\end{array}$ & $\begin{array}{l}124 \\
76\end{array}$ & $\begin{array}{l}100 \\
72\end{array}$ & $\begin{array}{c}24 \\
4\end{array}$ & $\begin{array}{l}19,3 \\
5,3\end{array}$ & $\begin{array}{c}1,02 \\
-1,31\end{array}$ \\
\hline 16. & $\begin{array}{l}\text { Розміщення гумово-трубчастого } \\
\text { дренажу при дренуванні: } \\
\text { Через рану } \\
\text { Класичні точки } \\
\text { Додаткове дренування } \\
\text { Дренаж типу "сигара" }\end{array}$ & $\begin{array}{c}9 \\
166 \\
21 \\
4\end{array}$ & $\begin{array}{c}7 \\
144 \\
19 \\
2\end{array}$ & $\begin{array}{c}2 \\
22 \\
2 \\
2\end{array}$ & $\begin{array}{c}28,57 \\
15,3 \\
10,53 \\
50\end{array}$ & $\begin{array}{l}1,70 \\
0,51 \\
0,83 \\
2,67\end{array}$ \\
\hline 17. & $\begin{array}{l}\text { Ускладнення зі сторони рани: } \\
\text { Інфільтрат } \\
\text { Серома } \\
\text { Нагноєння } \\
\text { Гематома } \\
\text { Розходження швів апоневрозу } \\
\text { (евентерація) } \\
\text { Розходження країв рани (евентерація) }\end{array}$ & $\begin{array}{l}9 \\
18 \\
12 \\
3 \\
8 \\
6\end{array}$ & $\begin{array}{l}9 \\
16 \\
11 \\
3 \\
\\
6 \\
3\end{array}$ & $\begin{array}{l}0 \\
2 \\
1 \\
0\end{array}$ & $\begin{array}{c}0 \\
11,1 \\
8,3 \\
0 \\
\\
25 \\
50\end{array}$ & $\begin{array}{c}0 \\
-0,76 \\
-1,06 \\
0 \\
1,47 \\
2,67\end{array}$ \\
\hline
\end{tabular}


Продовження табл. 1

\begin{tabular}{|c|c|c|c|c|c|c|}
\hline \multirow{3}{*}{$\begin{array}{l}\text { № } \\
3 / \Pi\end{array}$} & \multirow{3}{*}{ Фактор } & \multirow{3}{*}{$\begin{array}{c}\text { Кількість } \\
\text { спостережень }\end{array}$} & \multicolumn{3}{|c|}{ Результат } & \multirow{3}{*}{$\begin{array}{c}\text { Значення, } \\
\text { бали }\end{array}$} \\
\hline & & & \multirow{2}{*}{$\begin{array}{c}\text { добрий } \\
\text { осіб }\end{array}$} & \multicolumn{2}{|c|}{ несприятливий } & \\
\hline & & & & осіб & $\%$ & \\
\hline 18. & $\begin{array}{l}\text { Ускладнення після операції: } \\
\text { Рання спайкова кишкова } \\
\text { непрохідність } \\
\text { Кишкова нориця } \\
\text { Абсцеси черевної порожнини } \\
\text { Післяопераційна пневмонія } \\
\text { Плеврит } \\
\text { Перикардит } \\
\text { Інфаркт міокарда } \\
\text { ТЕЛА } \\
\text { Поліорганна недостатність } \\
\text { Тривалий парез кишечника } \\
\text { Тромбоз глибоких вен н/к } \\
\text { Тромбофлебіт н/к } \\
\text { Післяопераційний панкреатит }\end{array}$ & $\begin{array}{c}27 \\
10 \\
17 \\
73 \\
46 \\
7 \\
14 \\
3 \\
93 \\
94 \\
11 \\
13 \\
45 \\
\end{array}$ & $\begin{array}{c}17 \\
4 \\
6 \\
48 \\
26 \\
1 \\
5 \\
0 \\
65 \\
68 \\
7 \\
12 \\
33\end{array}$ & $\begin{array}{c}10 \\
6 \\
11 \\
25 \\
20 \\
6 \\
9 \\
3 \\
28 \\
26 \\
4 \\
1 \\
12\end{array}$ & $\begin{array}{c}37,0 \\
60 \\
64,7 \\
34,2 \\
43,5 \\
85,7 \\
64,3 \\
100 \\
30,1 \\
27,6 \\
36,4 \\
7,8 \\
26,7\end{array}$ & $\begin{array}{c}2,13 \\
3,02 \\
3,17 \\
2 \\
2,42 \\
3,77 \\
3,16 \\
4,13 \\
1,78 \\
1,64 \\
2,11 \\
-1,11 \\
1,58\end{array}$ \\
\hline 19. & $\begin{array}{c}\text { Кількість проведених лапаротомій: } \\
1 \text { раз } \\
2 \text { рази } \\
>2 \text { раз } \\
\end{array}$ & $\begin{array}{c}13 \\
10 \\
5\end{array}$ & $\begin{array}{l}9 \\
6 \\
2\end{array}$ & $\begin{array}{l}4 \\
4 \\
3\end{array}$ & $\begin{array}{c}30,8 \\
40 \\
60\end{array}$ & $\begin{array}{l}1,82 \\
2,30 \\
3,02\end{array}$ \\
\hline 20. & 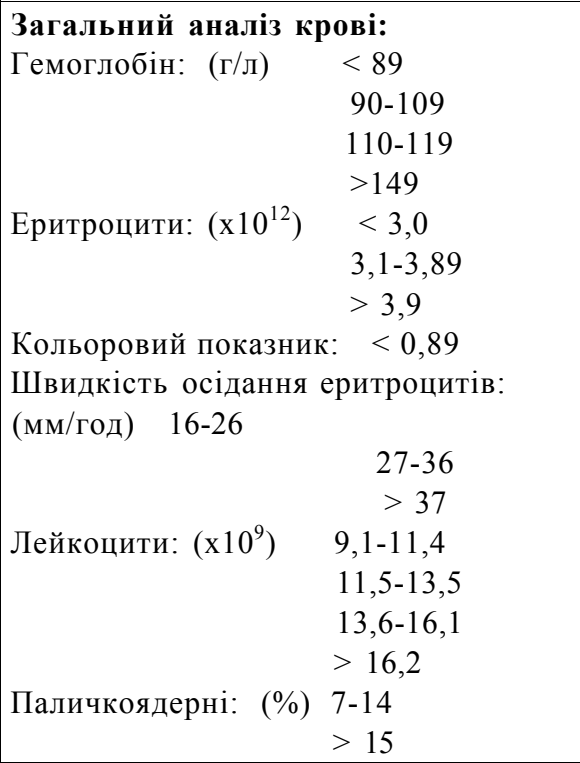 & $\begin{array}{c}17 \\
158 \\
16 \\
9 \\
24 \\
153 \\
23 \\
186 \\
\\
137 \\
28 \\
35 \\
23 \\
36 \\
96 \\
45 \\
168 \\
32 \\
\end{array}$ & $\begin{array}{c}10 \\
141 \\
12 \\
9 \\
9 \\
140 \\
23 \\
169 \\
131 \\
12 \\
29 \\
18 \\
30 \\
82 \\
42 \\
150 \\
22\end{array}$ & $\begin{array}{c}6 \\
16 \\
6 \\
5 \\
6 \\
14 \\
3 \\
18 \\
10\end{array}$ & $\begin{array}{c}41,2 \\
10,7 \\
25 \\
0 \\
62,5 \\
8,5 \\
0 \\
9,1 \\
\\
4,4 \\
57,1 \\
17,1 \\
21,7 \\
16,7 \\
14,6 \\
6,7 \\
10,7 \\
31,2 \\
\end{array}$ & $\begin{array}{c}2,32 \\
-0,81 \\
1,47 \\
0 \\
3,10 \\
-1,04 \\
0 \\
-0,98 \\
\\
-1,38 \\
2,92 \\
0,78 \\
1,23 \\
0,73 \\
0,34 \\
-1,20 \\
-0,81 \\
1,84\end{array}$ \\
\hline 21. & $\begin{array}{ll}\text { Біохімічний аналіз крові: } \\
\text { АсАТ (од/л): } & <0,44 \\
& 0,45-0,90 \\
& >0,91 \\
\text { АлАТ (од/л): } & <0,45 \\
& 0,50-0,90 \\
& >0,91 \\
\text { Загальний білок (г/л): } & <55 \\
& 56-65 \\
\text { Альбуміни (\%): } & <35 \\
\text { Креатинін (мкмоль/л): } & <54 \\
& 115-150 \\
& >151 \\
\text { Сечовина (мкмоль/л): } & \\
8,4 & -14,31\end{array}$ & $\begin{array}{c}22 \\
157 \\
21 \\
34 \\
148 \\
18 \\
72 \\
128 \\
25 \\
175 \\
8 \\
69 \\
123 \\
107 \\
\end{array}$ & $\begin{array}{c}22 \\
144 \\
6 \\
34 \\
127 \\
10 \\
56 \\
116 \\
6 \\
175 \\
8 \\
64 \\
100 \\
101 \\
\end{array}$ & $\begin{array}{c}0 \\
13 \\
15 \\
0 \\
21 \\
8 \\
16 \\
12 \\
19 \\
0 \\
0 \\
5 \\
23\end{array}$ & $\begin{array}{c}0 \\
8,3 \\
71,4 \\
0 \\
14,2 \\
44,4 \\
22,2 \\
9,4 \\
76 \\
0 \\
0 \\
7,2 \\
18,7 \\
\end{array}$ & $\begin{array}{c}0 \\
-1,06 \\
3,37 \\
0 \\
0,20 \\
2,45 \\
1,27 \\
-0,95 \\
3,50 \\
0 \\
0 \\
-1,16 \\
0,96 \\
-1,29\end{array}$ \\
\hline
\end{tabular}


Продовження табл. 1

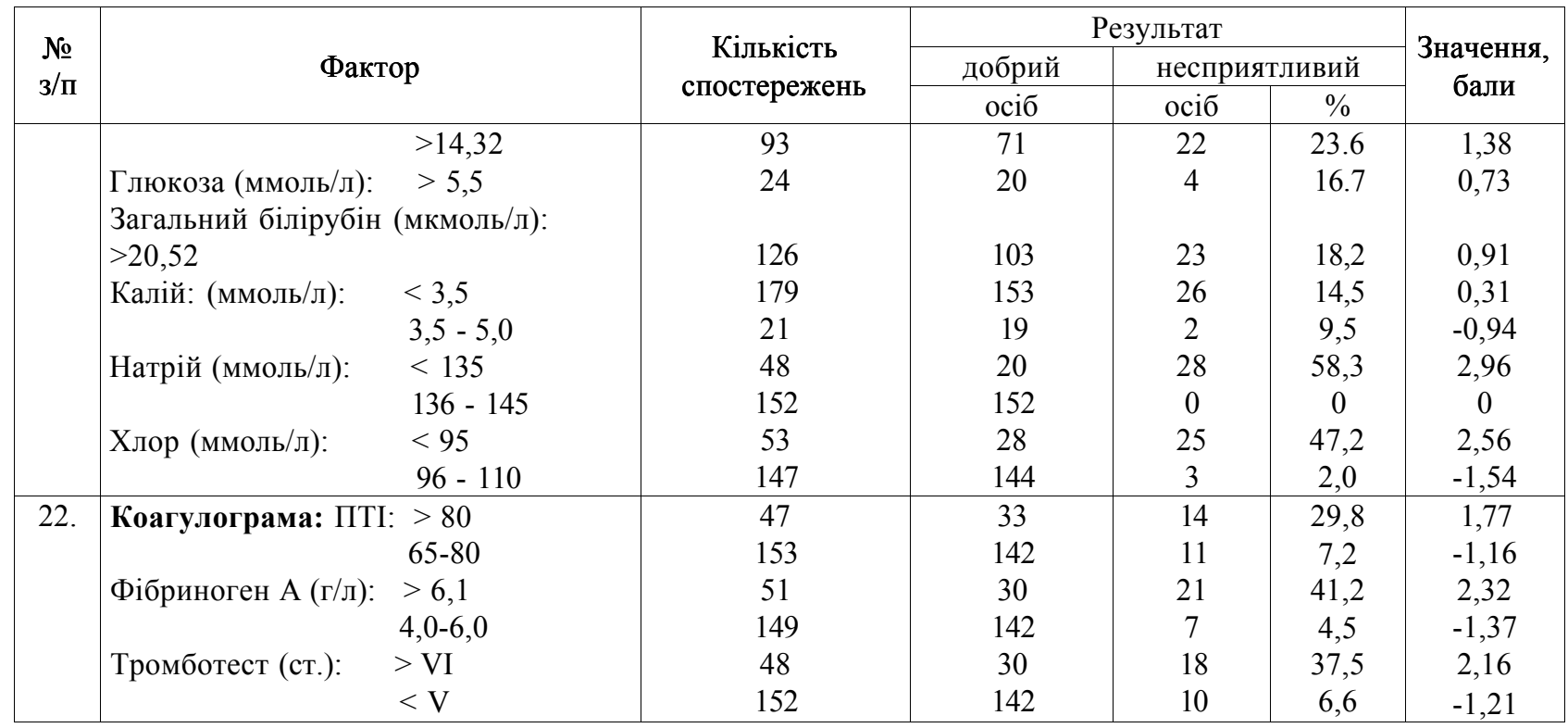

Примітка: Середня частота несприятливих результатів в усіх випадках складала 14 \%.

Таблиця 2. Прогностична значимість факторів, що визначають ускладнення перебігу перитоніту

\begin{tabular}{|c|c|}
\hline Фактори ризику погіршення при місцевому перитоніті & Бали \\
\hline Жіноча стать & 0,71 \\
\hline Вік 61 - 75 років & 1,29 \\
\hline 76 - 90 років & 2,17 \\
\hline$>90$ років & 4,13 \\
\hline Госпіталізація через 48 годин & 1,78 \\
\hline Госпіталізація через 48 - 72 години & 1,95 \\
\hline$>72$ годин & 2,34 \\
\hline Проживання в селі & 1,99 \\
\hline Перенесені захворювання: інсульт & 2,75 \\
\hline Інфаркт міокарда & 2,72 \\
\hline Гепатит & 2,09 \\
\hline Алергія & 0,91 \\
\hline Куріння & 1,3 \\
\hline Гострий тромбоз мезентеріальних судин & 4,13 \\
\hline Гострий калькульозний холецистит & 1,27 \\
\hline Защемлена грижа & 1,27 \\
\hline Гострий перфоративний апендицит & 1,20 \\
\hline Гостра кишкова непрохідність & 0,83 \\
\hline Перфорація кишки & 0,73 \\
\hline Характер ексудату: гнійно-фібринозний & 1,38 \\
\hline Характер ексудату: жовчний & 1,70 \\
\hline Характер ексудату: каловий & 1,89 \\
\hline Супутня патологія: порушення серцевого ритму & 2,57 \\
\hline Гіпертонічна хвороба II-IIIст. & 1,89 \\
\hline Цукровий діабет II тип & 1,09 \\
\hline Ожиріння II-ІУст. & 1,87 \\
\hline Анемія & 1,75 \\
\hline Захворювання печінки & 1,72 \\
\hline Захворювання нирок & 2,02 \\
\hline Ревматична хвороба серця & 2,23 \\
\hline Варикозна хвороба нижніх кінцівок & 1,90 \\
\hline
\end{tabular}


Продовження табл. 2

\begin{tabular}{|c|c|}
\hline Фактори ризику погіршення при місцевому перитоніті & Бали \\
\hline 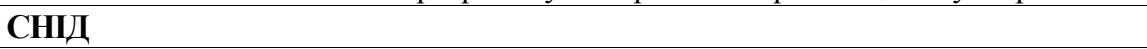 & 1,27 \\
\hline Пульс > 110 уд/хв & 0,61 \\
\hline Термінальна фаза перитоніту & 3,03 \\
\hline Ліквідація непрохідності + резекція кишечника & 0,91 \\
\hline Виведення двостовбурового ануса & 2,67 \\
\hline Холецистектомія (відкрита) & 2,27 \\
\hline Грижовисікання з резекцією кишечника & 2,45 \\
\hline Не оперований & 4,13 \\
\hline Тривалість операції: $120-180$ хв & 1,19 \\
\hline Тривалість операції : >180 хв & 1,95 \\
\hline Використання р-ну фурациліну для санації черевної порожнини & 1,02 \\
\hline Дренування через рану & 1,70 \\
\hline Використання дренажів типу "сигара" & 2,67 \\
\hline Евентрація (повна) & 2,67 \\
\hline Тромбоз глибоких вен нижніх кінцівок & 2,11 \\
\hline Рання кишкова непрохідність & 2,13 \\
\hline Плеврит & 2,43 \\
\hline Кишкова нориця (тонкокишкова) & 3,02 \\
\hline Абсцеси черевної порожнини & 3,17 \\
\hline Інфаркт міокарда & 3,16 \\
\hline Перикардит & 3,77 \\
\hline ТЕЛА & 4,13 \\
\hline К-ть проведених релапаротомій: 1 раз & 1,82 \\
\hline 2 рази & 2,30 \\
\hline$>2$ pa3 & 3,02 \\
\hline Гемоглобін: $\quad$ < 89 (г/л) & 2,32 \\
\hline Еритроцити: (х10 ) <3,0 & 3,10 \\
\hline Швидкість осідання еритроцитів: (мм/год) 27-36 & 2,92 \\
\hline Паличкоядерні: (\%) > 15 & 1,84 \\
\hline Коагулограма: ПТІ (\%) > 80 & 1,77 \\
\hline Фібриноген А: (г/л) > $>6,0$ & 2,32 \\
\hline Тромботест: (ст.) > VI & 2,16 \\
\hline Загальний білок: (г/л) < 55 & 1,27 \\
\hline Альбуміни: $(\%)<35$ & 3,50 \\
\hline Сечовина (кмоль/л) > 14,32 & 1,38 \\
\hline Креатинін: (мкмоль/л) >151 & 0,96 \\
\hline Натрій (ммоль/л) < 135 & 2,96 \\
\hline AcАТ (од/л) > 0,91 & 3,37 \\
\hline АлАТ (од/л) > 0,91 & 2,45 \\
\hline
\end{tabular}

зику. Припускали також, що прогноз буде визначатися сумою балів, що характеризують важливість симптомів, виявлених у хворих. Первісне число прогностичних ознак було більшим, однак перевірка кореляційних зв'язків дозволила скоротити їхню кількість за рахунок виключення менш значимих.

При аналізі факторів, що погіршують перебіг розлитого перитоніту, найбільш вагомими є жіноча стать та вік. У пацієнтів старше 60 років ризик негативного перебігу перитоніту зростає прямо пропорційно зі збільшенням віку. Так, у віці 61 - 75 років цей показник склав 1,29 бала, а в 76 - 90 років - 2,17 бала, тобто показник збільшувався в 2 рази. У віці 90 років i більше різко зростає ймовірність погіршення прогнозу, тому прогностичне значення цього показника сягає більше 4 балів. Час до госпіталізації у стаціонар відіграє важливу роль: якщо він не перебільшує 48 годин, то фактор ризику складає 1,78 бали, подовження терміну до госпіталізації більше 72 годин значно збільшує негативний вплив на перебіг захворювання. 3 цим показником опосередковано пов'язаний такий фактор ризику, як проживання в селі, оскільки віддаленість від лікувального закладу призводить до пізньої госпіталізації.

Окремо розглядали серед факторів високого ризику перенесені в анамнезі соматичні захворювання. 
Перше місце за прогностичною значущістю займає інсульт - 2,75, далі інфаркт міокарда - 2,72 та гепатити - 2,09 бали.

Серед хірургічних захворювань найбільш високий фактор ризику становить гострий тромбоз мезентеріальних судин (прогностична вага дорівнює 4,13), гострий калькульозний холецистит та защемлена грижа - 1,27, гострий перфоративний апендицит - 1,20, гостра кишкова непрохідність - 0,83 та перфорація кишечника- 0,73 бала.

При порівнянні характеру ексудату найвищий фактор ризику має каловий ексудат - 1,89 бала, жовчний - 1,70 та гнійно-фібринозний - 1,38 бала.

Супутня патологія також погіршує перебіг розлитого перитоніту. Досить високим фактором ризику є порушення серцевого ритму, ревматична хвороба серця, що складає 2,57 та 2,23 бала відповідно, захворювання нирок - 2,02, варикозна хвороба нижніх кінцівок - 1,9, гіпертонічна хвороба II-III ст. та ожиріння II-IV ст. - 1,89 та 1,87 бала відповідно. Більше одного бала складають такі захворювання як анемія, захворювання печінки, цукровий діабет II типу та СНІД.

При об'єктивному обстеженні пацієнта високим фактором ризику є тахікардія > 110 уд/хв $(0,61)$, що характеризує наявність шоку. Термінальна фаза перитоніту є найбільш тяжкою в перебігу та прогнозуванні несприятливого наслідку (відповідне значення $\mathrm{t}$ - критерію дорівнює 3,03).

Неоперовані хворі мають найгірший прогноз щодо життя і фактор ризику становить 4,13 бали. Найбільш травматичними оперативними втручаннями виявилися операції грижовисікання з резекцією тонкого кишечника (2,45 бала), відкрита холецистектомія (2,27 бала) та ліквідація непрохідності з резекцією кишечника (0,91 бала). Виведення двостовбурового ануса (2,67 бали) не належить до складних операцій, але займає особливе місце, оскільки проводиться при ракових пухлинах кишечника різної локалізації і тому супроводжується високою смертністю.

Оптимальна тривалість оперативного втручання повинна становити до 120 хвилин. При збільшенні тривалості до 180 хвилин погіршується післяопераційний перебіг та підвищується ризик летального наслідку, t- критерій становить 1,19 , а при тривалості > 180 хвилин - 1,95. Винятком є пацієнти в термінальній фазі перитоніту, яким проводиться діагностичне лапароскопічне втручання, що триває до 60 хвилин, проте закінчується летальним наслідком, спричиненим не тривалістю операції, а основним захворюванням.

Важливе значення під час операції має вибір розчину для санації черевної порожнини та вид дренування. Зокрема, нами встановлено, що використання розчину фурациліну не дає високого терапевтичного ефекту і сприяє раннім післяопераційним ускладненням (1-критерій 1,02), що підтверджено мікробіологічними дослідженнями. Високий фактор ризику становлять використання дренажів типу "сигара" $(2,67$ бали) та дренування через рану.

При аналізі післяопераційних ускладнень вони були поділені на соматичні, ускладнення зі сторони живота та рани.

Найбільш високий летальний ризик мали ТЕЛА 4,13 бала, перикардит - 3,77, інфаркт міокарда - 3,16, плеврит - 2,43 та тромбоз глибоких вен нижніх кінцівок - 2,11 бала. Ускладненнями зі сторони живота, що мали найбільш несприятливий вплив на перебіг захворювання, були абсцеси черевної порожнини - 3,17, кишкові нориці - 3,02 та рання кишкова непрохідність. Зі сторони рани - евентрація, 2,67 бала.

Кількість проведених релапаротомій також має прогностично несприятливий наслідок для життя пацієнта. Нами встановлено, що при одноразовій релапаротомії Іжритерій дорівнює 1,82 , при дворазовому іiї проведенні збільшується до 2,30, а при більше ніж дворазовій зростає до 3,02. 3 кожним проведенням релапаротомії виснажуються захисні можливості організму, що приводить до летального наслідку.

Характерним відображенням перебігу перитоніту $\epsilon$ проведений аналіз лабораторних показників. Найбільш прогностично цінними є рівень гемоглобіну - 2,32, кількість еритроцитів - 3,10, ШОЕ - 2,92, високий показник паличкоядерних нейтрофілів - 1,84 бала. Високу прогностичну цінність мають такі біохімічні показники як загальний білок - 1,27, альбуміни $<35 \%$ - 3,5 бала, АсАТ - 3,37, АлАТ - 2,45. Дані лабораторного аналізу характеризують інтоксикаційний синдром та тяжкість перебігу перитоніту. Більшість отриманих показників мають високу інформаційно-клінічну цінність, корелюють $з$ даними літератури й відрізняються тільки тим, що кількісно характеризують тяжкість захворювання.

Отже, можна вважати, що виділені та сформовані фактори ризику, наведені в роботі, будуть сприяти правильному прийняттю рішення при виборі обсягу консервативного й оперативного лікування в даній категорії хворих.

Висновки. 1. Провідними факторами в оцінюванні ризику перебігу та результатів хірургічного лікування розлитого перитоніту є жіноча стать, вік 60 - 90 років і більше, час до госпіталізації понад 48 годин, проживання в сільській місцевості, наявність в анамнезі інсульту, інфаркту міокарда, порушення серцевого ритму, калового, жовчного та гнійно-фібринозного ексудату, термінальної фази перебігу, операцій з ре- 
зекцією кишечника та таких післяопераційних ускладнень як ТЕЛА, плеврит, післяопераційна пневмонія, інфаркт міокарда, тромбоз глибоких вен нижніх кінцівок. У прогнозуванні результату комплексного лікування перитоніту варто також враховувати біохімічні показники.

\section{Література}

1. Сепсис и полиорганная недостаточность / Саенко В. Ф., Десятерик В. И., Перцева Т. А [и др.] - Кривой Рог : Минерал, 2005. - $466 \mathrm{c}$.

2. Полянський I. Ю. Лікувальна тактика при гострому перитоніті / І. Ю. Полянський // Шпитальна хірургія. - 2004. № 4. - С. 28-30.

3. Оптимізація програми комплексного лікування хворих 3 розповсюдженим гнійним перитонітом / Годлевський А. I., Кацал В. А., Саволюк С. І., Годлевська Н. А. // Матеріали XXI з'їзду хірургів України. - Запоріжжя, 2005. - Т 2. - С. $453-454$.

4. Прогнозирование исхода перитонита с использованием интегральных гематологических показателей / В. А. Сип-
2. Аналіз факторів ризику надає можливість створення схеми визначення ризику клінічного перебігу розлитого перитоніту, що дозволить кількісно оцінити важкість вихідного стану хворих і забезпечити коректне прогнозування результатів лікування захворювання.

ливый, Е. В. Конь, Л. В. Евтушенко [и др.] // Харьківська хірургічна школа. - 2009. - №2(2). - С. 188 - 189.

5. Гусев А. В. Обзор медицинских информационных систем на отечественном рынке в 2005 году / А. В. Гусев, Ф. А. Романов, И. П. Дуданов // Медицинский академический журнал. - 2005. - Т. 5, - № 3. - С. 72 - 84.

6. Мінцер О.П., Москаленко В. 3., Веселий С.В. Інформаційні технології в хірургії. - Кн. 3 в 10 книгах "Інформаційні технології в охороні здоров'я і практичній медицині". - К. : Вища школа, 2004. - 423 с.

7. Амосов Н. М. Факторы риска протезирования митрального клапана / Н. М. Амосов, Л. Н. Сидоренко, О. П. Минцер // Грудная хирургия. - 1975. - №9 3. - С. 9-16. 